\title{
Effect of Calcium on Superoxide Production by Phagocytic Vesicles from Rabbit Alveolar Macrophages
}

\author{
P. Daniel Lew and Thomas P. Stossel, Hematology-Oncology Unit, \\ Massachusetts General Hospital, Department of Medicine, \\ Harvard Medical School, Boston, Massachusetts 02114
}

\begin{abstract}
A B S T RACT Phagocytic vesicles from rabbit lung macrophages produced superoxide in the presence of $\mathrm{NADH}$ or $\mathrm{NADPH}$. At $37^{\circ} \mathrm{C}$, these vesicles generated $51 \pm 7.8 \mathrm{nmol} \mathrm{O}_{2}^{-} / \mathrm{min}$ per $\mathrm{mg}$ protein in the presence of $0.5 \mathrm{mM}$ NADPH. The apparent $K_{\mathrm{m}}$ for NADPH and NADH (66 and $266 \mu \mathrm{M}$, respectively), the pH optimum for the reaction (6.9), and the cyanide insensitivity were similar to properties of plasma membrane-rich fractions of stimulated polymorphonuclear leukocytes studied by others. The activity of the phagocytic vesicles was trypsin sensitive. The specific superoxidegenerating activity of macrophage phagocytic vesicles isolated from cells incubated up to $90 \mathrm{~min}$ with phagocytic particles remained constant.
\end{abstract}

Calcium in micromolar concentrations inhibited the NADPH-dependent $\mathrm{O}_{2}^{-}$-generating activity of phagocytic vesicles. In a physiological ionic medium (100 $\mathrm{mM} \mathrm{KCl}, 2.5 \mathrm{mM} \mathrm{MgCl}, 30 \mathrm{mM}$ imidazole- $\mathrm{HCl}, \mathrm{pH}$ 6.9), a maximal inhibition of $\mathrm{O}_{2}^{-}$generation by phagocytic vesicles of $80 \%$ was observed at $40 \mu \mathrm{M}$ free $\mathrm{Ca}^{2+}$. The half maximum inhibitory effect was at $0.7 \mu \mathrm{M}$ $\mathrm{Ca}^{2+}$. Variations of the calcium concentration resulted in rapid and reversible alterations in $\mathrm{O}_{2}^{-}$-forming activity. Preincubation of phagocytic vesicles in the presence of EGTA rendered their $\mathrm{O}_{2}^{-}$generation rate in the presence of NADPH insensitive to alterations in the free calcium concentration. This desensitization by low EGTA concentrations $(\leq 100 \mu \mathrm{M})$ was reversible by the addition of excess calcium, but desensitization by high EGTA concentrations $(>1 \mathrm{mM})$ was not reversible by the addition of calcium either in the presence or absence of purified rabbit lung macrophage or bovine brain calmodulins. Furthermore, trifluoperazine, a drug that inhibits calmodulin-stimulated reactions, did not alter the activity or the calcium sensitivity of the superoxide-generating system of sensitive phagocytic vesicles.

Received for publication 7 July 1980 and in revised form 25 August 1980.
Peripheral plasma membrane vesicles (podosomes) prepared by gentle sonication of macrophages possessed an $\mathrm{O}_{2}^{-}$-generating system with similar properties to those of phagocytic vesicles.

We conclude that the activated $\mathrm{O}_{2}^{-}$-generating system of rabbit lung macrophages has its initial localization in the plasmalemma and undergoes subsequent internalization into phagocytic vesicles, where it can function for prolonged periods of time. Calcium at concentrations likely to exist in macrophage cytoplasm exerts a regulatory effect on the activated system.

\section{INTRODUCTION}

Mammalian phagocytes encountering objects that they recognize convert oxygen molecules to superoxide anions $\left(\mathrm{O}_{2}^{-}\right)$, hydrogen peroxide, and other substances important for microbicidal activity. Reduced pyridine nucleotide oxidase enzymes are the mediators of this respiratory reaction (1). The activation of oxygen metabolism in phagocytes appears to be a process distinct from that maintaining its activity, because experimental manipulations that inhibit activation of the respiratory activity of phagocytes do not necessarily inhibit the activity of the respiratory rate after activation $(2,3)$. In view of recent evidence that calcium concentrations in the micromolar range can control the activity of peripheral cytoplasmic proteins involved in phagocytosis (4), it is logical to inquire whether this ion also influences the oxygen metabolism of the cells.

In the present investigation, we report that phagocytic vesicles from rabbit alveolar macrophages contain a reduced pyridine nucleotide-linked $\mathrm{O}_{2}^{-}$-generating system that is inhibited by concentrations of free calcium expected to occur at times in the cytoplasm.

\section{METHODS}

Isolation of macrophages. Cells were obtained from the lungs of New Zealand white rabbits by the procedure of Myrvik et al. (5), as described previously (6), 14-21 d after 
the animals received an intravenous injection of $1 \mathrm{ml}$ of Freund's complete adjuvant to increase cell yields. The cells, suspended in $0.15 \mathrm{M} \mathrm{NaCl}$ solution, were washed three times at $4^{\circ} \mathrm{C}$ by centrifugation $(250 \mathrm{~g}, 10 \mathrm{~min})$, suspended in a modified Krebs-Ringer phosphate medium $(130 \mathrm{mM} \mathrm{NaCl}$, $4 \mathrm{mM} \mathrm{KCl}, 1.3 \mathrm{mM} \mathrm{MgCl}, 1 \mathrm{mM} \mathrm{CaCl}$, and $10 \mathrm{mM}$ sodium phosphate buffer, pH 7.4, hereafter designated as "medium"), and kept at $0^{\circ} \mathrm{C}$ until use. Yields ranged from $3 \times 10^{8}$ to $2.4 \times 10^{9}$ cells/rabbit, of which $>90 \%$ were macrophages.

Serum preparation. Rabbit serum was obtained from freshly clotted blood derived from anesthetized animals by cardiac puncture. Sera were used on the same day or stored at $-70^{\circ} \mathrm{C}$ until use.

Purification of phagocytic vesicles. This technique, described in detail elsewhere (6), is outlined briefly. Diisodecylphthalate $(1 \mathrm{ml})$ (practical grade, Matheson, Coleman and Bell, E. Rutherford, N. J.) was added to $3 \mathrm{ml}$ of medium containing $10 \mathrm{mg} / \mathrm{ml}$ of Escherichi coli lipopolysaccharide 026:B6 (Difco Laboratories, Detroit, Mich.) and emulsified by sonication. The lipopolysaccharide-coated diisodecylphthalate particles were incubated with fresh or freshly thawed rabbit serum for $20 \mathrm{~min}$ at $37^{\circ} \mathrm{C}$, during which time an opsonic fragment of the third component of complement was deposited on them (7) (opsonized particles). Cells were suspended in medium and warmed to $37^{\circ} \mathrm{C}$. Suspensions of opsonized particles $(20 \%, \mathrm{vol} / \mathrm{vol})$ and cells $(5 \%, \mathrm{vol} / \mathrm{vol})$ were mixed and agitated gently in a shaking bath at $37^{\circ} \mathrm{C}$ for various amounts of time, during which the cells ingested the opsonized particles. The cells were washed once in cold $0.15 \mathrm{M}$ $\mathrm{NaCl}$, suspended in ice-cold deionized water, and immediately centrifuged at $4^{\circ} \mathrm{C}$. During this treatment, which made subsequent homogenization easier, the cells swelled but did not break. The cell pellets were suspended in equal volume of ice-cold $0.34 \mathrm{M}$ sucrose solution containing $5 \mathrm{mM}$ EGTA and $30 \mathrm{mM}$ imidazole- $\mathrm{HCl}, \mathrm{pH}$ 7.4. The cells were homogenized in this medium in a $40 \mathrm{ml}$ Dounce homogenizer with a tightly fitting pestle. The progress of cell rupture was monitored as the percentage of free nuclei visible by phasecontrast microscopy. About $\mathbf{5 0}$ strokes were required to break $90 \%$ of the cells. In most experiments, $\mathrm{Ca}^{2+}\left(\mathrm{CaCl}_{2}\right)$ was then added to a final concentration of 4-5 mM. As explained in Results, the concentration of added calcium was important in the properties of the subsequently purified phagocytic vesicles. EGTA was used at this step because it increases considerably the efficiency of homogenization. The homogenate was transferred to a $30-\mathrm{ml}$ Sorvall centrifuge tube (DuPont Instruments-Sorvall Biomedical Div., DuPont Co., Newtown, Conn.), carefully overlaid by means of a peristaltic pump (Pharmacia Fine Chemicals, Piscataway, N. J.) with 2 vol of a solution containing $0.25 \mathrm{M}$ sucrose, $30 \mathrm{mM}$ imidazole- $\mathrm{HCl}, \mathrm{pH} 6.9$, and concentrations of calcium or EGTA, and centrifuged for 60 $\min$ at $150,000 \mathrm{~g}$. The floating white layer, representing isolated phagocytic vesicles, was then carefully removed and kept at $0^{\circ} \mathrm{C}$ until it was further diluted for use. The protein concentration of phagocytic vesicles was determined by the Folin procedure (8).

Preparation of peripheral hyaline vesicles of macrophages (podosomes). This preparation, containing a mixture of rightside-out and inside-out blebs of plasma membrane and virtually free of organelles, was prepared by gentle sonication of a warm suspension of cells according to previously published techinques (9). In brief, macrophages $\left(10^{8}\right.$ cells $)$ were incubated for $4 \mathrm{~min}$ at $37^{\circ} \mathrm{C}$ in glass conical centrifuge tubes with or without $50 \mu \mathrm{g}$ of digitonin in $5 \mathrm{ml}$ of medium with 5 $\mathrm{mM}$ glucose. After incubation, the suspension was placed in a $37^{\circ} \mathrm{C}$ temperature sonication bath (Branson Ultrasonic Cleaner, model B 12, purchased from Heat Systems-Ultrasonics, Inc., Plainview, N. Y.) for 8-10 s. The vesicles were separated from residual cell bodies by sedimenting the latter $(250 \mathrm{~g}, 10 \mathrm{~min})$ and pelleting the resultant supernate. The pellet was washed in a solution containing $0.25 \mathrm{M}$ sucrose, $30 \mathrm{mM}$ imidazole$\mathrm{HCl}, \mathrm{pH} 6.9$, resuspended in the same solution, and kept at $0^{\circ} \mathrm{C}$ until used.

Assay of $\mathrm{O}_{2}^{-}$production by phagocytic vesicles and podosomes. $\mathrm{O}_{2}^{-}$production by phagocytic vesicles or podosomes was assayed by examining the rate of $\mathrm{O}_{2}^{-}$dependent cytochrome $c$ reduction in the presence of reduced pyridine nucleotides in a Gilford spectrophotometer 250 (Gilford Instrument Laboratories, Inc., Oberlin, Ohio) with a controlled temperature regulator. This assay is based on methods used by previous investigators (2).

The standard assay system contained the following, in a total volume of $0.8 \mathrm{ml}$ : cytochrome $c$ type VI $(50 \mathrm{nmol})$, NADPH $(0.5 \mu \mathrm{mol})$ or NADH $(2 \mu \mathrm{mol})$ (all from Sigma Chemical Co., St. Louis, Mo.), in a medium containing $\mathrm{KCl}(0.1 \mathrm{mmol})$, $\mathrm{MgCl}_{2}(2.5 \mu \mathrm{mol})$, and imidazole-HCl $(24 \mu \mathrm{mol}) \mathrm{pH}$ 6.9. In some experiments, sucrose $(0.25 \mathrm{mmol})$ replaced $\mathrm{KCl}$. Various concentrations of $\mathrm{CaCl}_{2}$ and EGTA were also added. In addition, superoxide dismutase $(30 \mu \mathrm{g})$ was added to the reference compartments of the spectrophotometer. The reactions were initiated by the addition of $0.2 \mathrm{ml}$ of phagocytic vesicles or podosomes to both the sample and reference cuvettes, and the absorbance changes at $550 \mathrm{~nm}$ were monitored by double-beam spectrophotometry. In addition, podosomes were tested in the presence of $\mathrm{KCN}(0.5$ $\mu \mathrm{mol}$ ) (10). An extinction coefficient of $19,500 \mathrm{~cm}^{-1}$ was used for (reduced minus oxidized) cytochrome $c$ (11). The sensitivity of this assay is such that it will detect rates of $\mathrm{O}_{2}^{-}$ production as low as $0.5 \mathrm{nmol} / \mathrm{min}$ (2).

For experiments in which enzyme activity was measured as a function of free calcium concentration, phagocytic vesicles were washed a second time in a medium containing $0.5 \mathrm{mg} / \mathrm{ml}$ bovine serum albumin, $0.25 \mathrm{M}$ sucrose, $30 \mathrm{mM}$ imidazole-HCl, $\mathrm{pH} 6.9,2.5 \mathrm{mM} \mathrm{MgCl}_{2}$, and $100 \mu \mathrm{M} \mathrm{CaCl}$. Samples of the washed vesicles were tested in the medium described above, in solutions containing various concentrations of calcium and EGTA. These experiments were performed at $25^{\circ} \mathrm{C}$ because the equilibrium constants for EGTA have been established at $20-25^{\circ} \mathrm{C}(12)$. The free $\mathrm{Ca}^{2+}$ concentration of solutions was calculated by means of the computer program of Perrin and Sayce as described by Potter and Gergeley (13). Trifluoperazine dihydrochloride (provided by Dr. Eileen Gallagher, SmithKline and French, Philadelphia, $\mathrm{Pa}$.) was preincubated with vesicles in the presence of 100 $\mu \mathrm{M}$ calcium at $0^{\circ} \mathrm{C}$ for $1 \mathrm{~h}$.

In some experiments, phagocytic vesicles and podosomes were treated with trypsin. Bovine pancreatic trypsin, type IX, treated with diphenyl carbonyl chloride to inactivate chymotrypsin (Sigma Chemical Co.), was dissolved at a concentration of $10 \mathrm{mg} / \mathrm{ml}$ in $100 \mathrm{mM} \mathrm{KCL}$ and $30 \mathrm{mM}$ imidazole- $\mathrm{HCl}$, pH 6.9. Vesicles were warmed to room temperature, and the trypsin solution was added to make a final concentration of $500 \mu \mathrm{g} / \mathrm{ml}$. After $5 \mathrm{~min}$ of incubation, soybean typsin inhibitor (Sigma Chemical Co.) in the same buffer solution was added to a final concentration of $500 \mu \mathrm{g} / \mathrm{ml}$. The suspension was immediately placed on ice after mixing. Controls contained soybean trypsin inhibitor added simultaneously with trypsin or no additions at all.

Assay of $\mathrm{O}_{2}^{-}$production of intact macrophages. Spectrophotometric measurements of $\mathrm{O}_{\mathbf{2}}^{-}$-dependent cytochrome $c$ reduction were performed with a continuous assay, as described above, at $25^{\circ} \mathrm{C}$. The sample cuvette contained cytochrome $c(50 \mathrm{nmol})$ and macrophages $\left(4 \times 10^{6}\right)$ with or without digitonin (10 $\mu$ g; Fisher Scientific Co., Pittsburgh, Pa.) in $1 \mathrm{ml}$ of medium with $5 \mathrm{mM}$ glucose. The lag time for activation, as well as the rate of activity of $\mathrm{O}_{2}^{-}$generation, was calculated as previously described by Cohen et al. $(2,3)$. 
Whole macrophages were treated with trypsin by the same procedure described for phagocytic vesicles. Analysis of basal oxidation of $\left[1-{ }^{14} \mathrm{C}\right]$ glucose by intact macrophages was performed as previously described (9).

Purification of macrophage calmodulin. Macrophages were suspended in an equal volume of ice-cold $0.34 \mathrm{M}$ sucrose solution containing $5 \mathrm{mM}$ EGTA, $5 \mathrm{mM}$ dithiothreitol, $1 \mathrm{mM}$ phenylmethylsulfonyl fluoride, $0.25 \mathrm{mg} / \mathrm{ml}$ of $\alpha$-1-antitrypsin, $0.25 \mathrm{mg} / \mathrm{ml}$ of soybean trypsin inhibitor, and $20 \mathrm{mM}$ imidazole- $\mathrm{HCl}$ buffer, $\mathrm{pH} \mathrm{7.4}$, and homogenized as described above. The homogenate was centrifuged at $100,000 \mathrm{~g}$ for $1 \mathrm{~h}$ and the supernatant fluid was dialyzed overnight against $10 \mathrm{mM}$ Hepes, $1 \mathrm{mM} \mathrm{CaCl}, \mathrm{pH} \mathrm{7,} \mathrm{and} \mathrm{frac-}$ tionated by affinity chromatography in a fluphenazine-agarose column. Fluphenazine (provided by Dr. Salvator Luciano, E. R. Squibb and Sons, Princeton, N. J.) was coupled to Sepharose activated by the bisoxarine procedure as described by Charbonneau and Cormier (14). The activity of activatordeficient phosphodiesterase (provided by Dr. Robert Wallace and Dr. Wai Yui Cheung, St. Jude Children's Research Hospital, Memphis, Tenn.) in the presence of column fractions was determined as described by Strewler et al. (15). The bulk of the protein passed directly through the column and had no phosphodiesterase-stimulating activity. A buffer solution containing $10 \mathrm{mM}$ Pipes, $\mathrm{pH} 7,1 \mathrm{mM} \mathrm{CaCl}$, and $0.5 \mathrm{M} \mathrm{NaCl}$ eluted a small peak of protein that also had no phosphodiesterase activator activity. A $10 \mathrm{mM}$ Pipes solution, pH 7, containing $10 \mathrm{mM} \mathrm{EGTA}$ and $0.5 \mathrm{M} \mathrm{NaCl}$, eluted a small protein peak that activated phosphodiesterase in a calcium-dependent manner. This activity was resistant to boiling. Polyacrylamide gel electrophoresis of this fraction in sodium dodecyl sulfate revealed a homogenous polypeptide that comigrated with bovine brain calmodulin (provided by Dr. Wallace and Dr. Cheung). The purified calmodulins were incubated with phagocytic vesicles that had been homogenized and suspended in various concentrations of EGTA at a concentration of $20 \mu \mathrm{g} / \mathrm{ml}$ in the presence of $100 \mu \mathrm{M}$ free $\mathrm{Ca}^{2+}$ for $1 \mathrm{~h}$ at $0^{\circ} \mathrm{C}$.

\section{RESULTS}

$\mathrm{O}_{2}^{-}$production by intact macrophages, macrophage podosomes, and macrophage phagocytic vesicles. As previously reported, rabbit alveolar macrophages stimulated with digitonin released $\mathrm{O}_{2}^{-}$in the absence of reduced pyridine nucleotides (3). After addition of digitonin to a cuvette containing macrophages and cytochrome $c$, there was an initial period with no change in $A_{550}$, then a gradual rise until a linear rate was achieved. At $25^{\circ} \mathrm{C}$, the lag time was $72 \pm 6 \mathrm{~s}$ and the rate of activity was $0.51 \pm 0.06 \mathrm{nmol} \mathrm{O}_{2}^{-} / 10^{6}$ cells per $\min$ (mean \pm SEM for three different cell preparations).

Trypsinization of the macrophages $\left(1,000 \mu \mathrm{g} / 2 \times 10^{7}\right.$ cells per $\mathrm{ml}$ for $5 \mathrm{~min}$ at room temperature) did not detectably alter the $\mathrm{O}_{2}^{-}$production rate of the cells. The addition of trifluoperazine, an agent that inhibits calmodulin-dependent reactions in the presence of calcium (16), inhibited the rate as well as the lag time of $\mathrm{O}_{2}^{-}$production (Fig. 1), whether added before or after the activation period, and the effect of the drug was complete $<1 \mathrm{~min}$ after the addition of the drug. Similar results were obtained using opsonized zymosan to stimulate $\mathrm{O}_{2}^{-}$release (not shown). Removal of

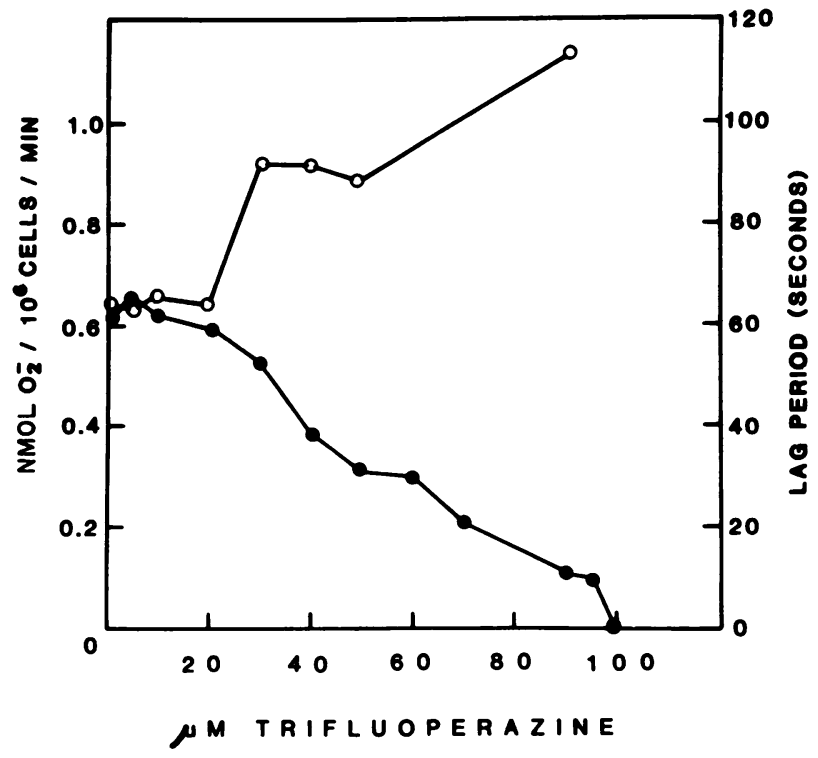

FIGURE 1 The effect of trifluoperazine on the rate $(0)$ and lag period (O) of $\mathrm{O}_{2}^{-}$generation by digitonin-stimulated rabbit alveolar macrophages. The indicated amounts of trifluoperazine were added at zero time and $\mathrm{O}_{2}^{-}$production measured as described in the text.

trifluoperazine by washing the cells did not restore the $\mathrm{O}_{2}^{-}$release rate to control values over a wide range of concentrations. Trifluoperazine up to $76 \mu \mathrm{M}$ did not inhibit the oxidation rates of $\left[1-\mathrm{C}^{14}\right]$ glucose of resting macrophages but impaired ${ }^{14} \mathrm{CO}_{2}$ release at higher concentrations (50\% decrease at $100 \mu \mathrm{M})$.

Phagocytic vesicles purified from macrophages that had ingested opsonized lipopolysaccharide-coated diisodecylphthalate particles were examined for their ability to generate $\mathrm{O}_{2}^{-}$in the presence of reduced pyridine nucleotides. At $25^{\circ} \mathrm{C}, \mathrm{O}_{2}^{-}$production was constant with time for about $4 \mathrm{~min}$, and under these conditions continuous production was detectable for $>30 \mathrm{~min}$. Both $\mathrm{NADH}$ and NADPH promoted $\mathrm{O}_{2}^{-}$ generation by the vesicles. The effect of the reduced pyridine nucleotides on the rate of $\mathrm{O}_{2}^{-}$production was not additive (not shown). $\mathrm{O}_{2}^{-}$generation by vesicles was not detectable in the absence of NADPH or NADH. The apparent $K_{m}$ for NADPH was 64 $\mu \mathrm{M}$, with a maximum oxidation rate $\left(\mathrm{V}_{\max }\right)$ of $29 \mathrm{nmol}$ $\mathrm{O}_{2}^{-} /$min per mg protein, whereas the apparent $K_{\mathrm{m}}$ for NADH was $266 \mu \mathrm{M}$ with a $V_{\max }$ of $19 \mathrm{nmol} \mathrm{O}_{2}^{-} / \mathrm{min}$ per mg protein (Fig. 2a). In contrast to NADPH, NADH elicited substantial cytochrome $c$ reduction in the presence of superoxide dismutase (up to $65 \%$ of the reduction rate in the absence of superoxide dismutase in NADH compared with up to $14 \%$ in NADPH). Therefore, most of our experiments were done in the presence of NADPH. The $\mathrm{O}_{2}^{-}$-generating activity in $0.5 \mathrm{mM}$ NADPH was directly proportional to the 

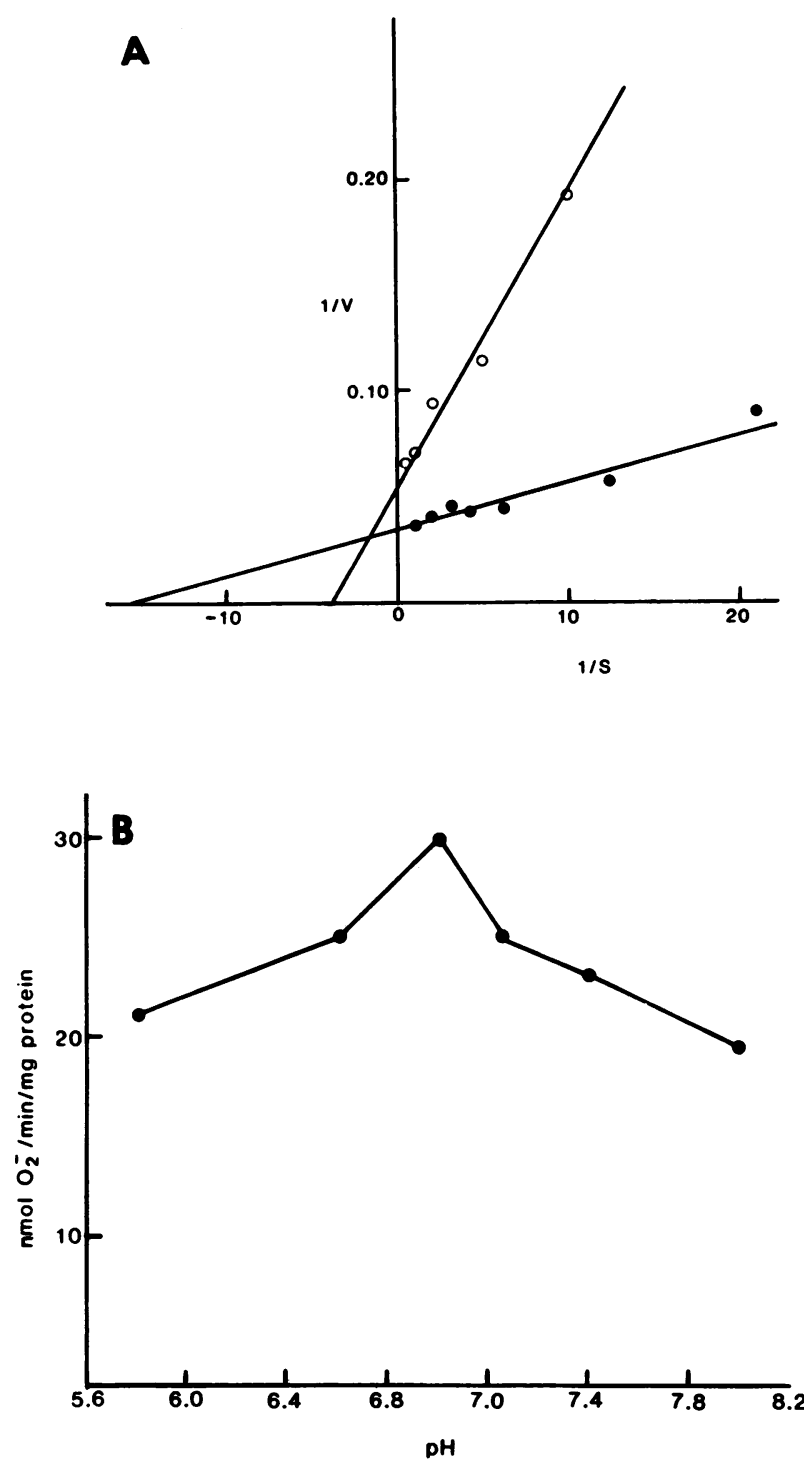

FIGURE 2 Rates of $\mathrm{O}_{2}^{-}$production by phagocytic vesicles from rabbit alveolar macrophages incubated at $25^{\circ} \mathrm{C}$ in a medium containing $0.25 \mathrm{M}$ sucrose, $30 \mathrm{mM}$ imidazole$\mathrm{HCl}, \mathrm{pH} 6.9,100 \mu \mathrm{M}$ EGTA, $2.5 \mathrm{mM} \mathrm{MgCl}_{2}, 50 \mathrm{nmol}$ cytochrome $c$, and $0.5 \mu \mathrm{mol}$ NADPH, unless otherwise specified. (A) NADH and NADPH oxidase kinetics: $\mathrm{O}_{2}^{-}$production was measured at varying concentrations of NADH (O) $(100-2,000 \mu \mathrm{M})$ and NADPH (O) (16-1,500 $\mu \mathrm{M})$. 1/V equals (nanomoles $\mathrm{O}_{\mathbf{2}}^{-}$generated per milligram vesicle protein per minute) ${ }^{-1}$; 1/S equals (millimoles NADPH or NADH per liter) ${ }^{-1}$. (B) pH optimum of $\mathrm{O}_{2}^{-}$production. The reaction was carried out in a medium containing $100 \mathrm{mM}$ $\mathrm{KCl}$ and $30 \mathrm{mM}$ imidazole- $\mathrm{HCl}$ at various $\mathrm{pH}$ values indicated.

concentrations of added vesicle protein between 10 and $132 \mu \mathrm{g} / \mathrm{ml}$. The $\mathrm{pH}$ optimum of this reaction was 6.9 (Fig. 2b).

Table I summarizes the effects of various conditions and additions on the initial rate of superoxide forma-
TABLE I

Effect of Temperature and Various Compounds on $\mathrm{O}_{2}^{-}$ Production by Phagocytic Vesicles from Rabbit Alveolar Macrophages

\begin{tabular}{lcc}
\hline \multicolumn{1}{c}{ Treatment } & \multicolumn{2}{c}{$\mathrm{O}_{2}^{-}$production } \\
\hline & nmol/min/mg protein \\
$37^{\circ} \mathrm{C}$ & \multicolumn{2}{c}{$51 \pm 7.8(5)$} \\
$25^{\circ} \mathrm{C}$ & $25 \pm 3.08(6)$ \\
$\mathrm{KCN}, 2 \mathrm{mM}^{*}$ & $25 \pm 2$ & $(3)$ \\
Azide, $5 \mathrm{mM}$ & $24 \pm 3$ & $(3)$ \\
ATP, $2.5 \mathrm{mM}$ & $22.75 \pm 1$ & $(2)$ \\
N-Ethyl maleimide, $1 \mathrm{mM}$ & $17.8 \pm 1.5(2)$ \\
Trypsin $\downarrow$ & 0 & $(3)$ \\
\hline
\end{tabular}

The activity was tested in a medium containing $0.25 \mathrm{M}$ sucrose, $2.5 \mathrm{mM} \mathrm{MgCl}_{2}, 30 \mathrm{mM}$ imidazole- $\mathrm{HCl}, \mathrm{pH} \mathrm{6.9}$, and $100 \mu \mathrm{M}$ EGTA at $25^{\circ} \mathrm{C}$, unless otherwise specified. All values are mean \pm SEM. Number of preparations is in parentheses.

* For this experiment, the reference cuvette contained 80 $\mu \mathrm{g}$ of superoxide dismutase to insure complete detection of the $\mathrm{O}_{2}^{-}$formed.

$\$ 500 \mu \mathrm{g}$ for $5 \mathrm{~min}$ at room temperature.

tion by vesicles in the presence of NADPH. The activity was diminished by $50 \%$ at $25^{\circ} \mathrm{C}$ when compared with $37^{\circ} \mathrm{C}$. The superoxide-generating activity was not significantly altered by addition of azide, cyanide, or $\mathrm{Mg}^{2+}$-ATP. $\mathrm{N}$-Ethyl maleimide decreased the activity by $30 \%$. Trypsinization rapidly and totally abolished this activity. If the vesicles were kept at ice temperature for several hours, a decrease in their activity was observed (about $30 \%$ after $3 \mathrm{~h}$ ). It was not possible to compare the specific activity of vesicles with that of homogenates from which they were derived, because of the presence of a powerful superoxide dismutase-resistant, cytochrome $c$-reducing activity, as well as the presence of large concentrations of superoxide dismutase (whether tested in the presence or absence of $0.5 \mathrm{mM} \mathrm{KCN}$ ) (17).

As shown in Fig. 3, the specific activity of $\mathrm{O}_{2}^{-}$generating activity in $0.5 \mathrm{mM}$ NADPH of phagocytic vesicles isolated from cells incubated with phagocytizable particles for up to $90 \mathrm{~min}$ was relatively constant.

Podosomes from resting and digitonin-stimulated macrophages were examined for their ability to generate $\mathrm{O}_{2}^{-}$in the presence of NADPH. In the presence of $0.5 \mathrm{mM}$ NADPH, podosomes obtained from resting cells generated $0.4 \mathrm{nmol} \mathrm{O}_{2}^{-} / \mathrm{mg}$ protein per min, whereas podosomes made from macrophages stimulated with digitonin for $4 \mathrm{~min}$ generated $3.2 \mathrm{nmol}$ $\mathrm{O}_{2}^{-} / \mathrm{mg}$ protein per min. $\mathrm{O}_{2}^{-}$generation by podosomes was not detectable in the absence of NADPH. Trypsinization inactivated the NADPH-dependent superoxide generation of podosomes. 




FIgURE 3 Specific activity of the NADPH-dependent $\mathrm{O}_{2}^{-}$production by phagocytic vesicles isolated from cells incubated with particles for varying lengths of time. Rabbit alveolar macrophages were incubated with opsonized lipopolysaccharide-coated oil particles for the times noted, and phagocytic vesicles were made as described in the text. NADPH-dependent $\mathrm{O}_{2}^{-}$production, $(O)$; total protein, (O).

Effect of calcium on the $\mathrm{O}_{2}^{-}$-forming activity of phagocytic vesicles and podosomes. The $\mathrm{O}_{2}^{-}$-generating activity of vesicles was very sensitive to the concentration of free calcium in the reaction media, provided that calcium was present in all the steps of the purification of the phagocytic vesicles (see below). Under physiologic ionic conditions $(100 \mathrm{mM} \mathrm{KCl}, 2.5$ $\mathrm{mM} \mathrm{MgCl}, 30 \mathrm{mM}$ imidazole $\mathrm{HCl}, \mathrm{pH} 6.9$ ), $0.1 \mathrm{mM}$ free $\mathrm{Ca}^{2+}$ inhibited the initial rate of superoxide formation in the presence of NADPH by $77 \pm 2 \%$ (mean \pm SEM for six separate preparations) when compared with the activity measured at $0.016 \mu \mathrm{M}$ free calcium.

Fig. 4 shows the effect of the free $\mathrm{Ca}^{2+}$ concentration on the rate of $\mathrm{O}_{2}^{-}$production. Inhibition of activity was directly proportional to the logarithm of the free $\mathrm{Ca}^{2+}$ concentration $(r=0.94$ by linear regression analysis), and the maximum inhibition was observed at a concentration of $40 \mu \mathrm{M}$ free $\mathrm{Ca}^{2+}$. The half maximum inhibitory effect was at a concentration of 0.7 $\mu \mathrm{M}$ free $\mathrm{Ca}^{2+}$.

If the vesicles were suspended in $0.25 \mathrm{M}$ sucrose instead of $0.1 \mathrm{M} \mathrm{KCl}$, the specific activity of the enzyme was not altered in the presence of low calcium concentrations. However, the inhibitory effect of calcium was less marked than in $0.1 \mathrm{M} \mathrm{KCl}$ solution. The half maximum inhibitory effect was at $3.5 \mu \mathrm{M}$ free $\mathrm{Ca}^{2+}$, and the inhibition of the $\mathrm{O}_{2}^{-}$formation rate in $0.1 \mathrm{mM}$ free $\mathrm{Ca}^{2+}$ was $48.44 \pm 4.89 \%$ (mean $\pm \mathrm{SEM}$ for six separate vesicle preparations). Phagocytic vesicles obtained from cells broken in the absence of added EGTA had calcium sensitivity indistinguishable from that of vesicles obtained from cells homogenized in EGTA, provided that the EGTA was neutralized after cell rupture by addition of $\mathrm{CaCl}_{2}$. The importance of the calcium concentration for maintaining calcium sensitivity is described further below.

As shown in Fig. 5, the effect of calcium on superoxide production by vesicles in a $0.1 \mathrm{M} \mathrm{KCl}$ solution and $0.5 \mathrm{mM}$ NADPH was rapid and reversible. In this experiment, the enzyme activity was continuously monitored in the presence of $40 \mu \mathrm{M}$ calcium. $400 \mu \mathrm{M}$ EGTA was then added to both compartments of the spectrophotometer, making the final free $\mathrm{Ca}^{2+}$ concentration $0.035 \mu \mathrm{M}$. After a lag period of $<1 \mathrm{~min}$, a threefold stimulation of the superoxide generation rate was observed. Several cycles of stimulation and inhibition under continuous monitoring could be observed, but with a progressive decrease in the measured activities. Similar effects were obtained using other calciumchelating agents such as EDTA or ATP. The onset of the stimulatory effect of decreasing the calcium concentration of superoxide production was identical after prolonged incubation of the vesicles either on ice (up to $2 \mathrm{~h}$ ) or at room temperature (up to $30 \mathrm{~min}$ ), provided that the gradual decrease in the specific activity previously mentioned was taken into account. Furthermore, if the enzyme activity in the presence of calcium was continuously monitored until no further $\mathrm{O}_{2}^{-}$was produced, the addition of EGTA stimulated new production of $\mathrm{O}_{2}^{-}$. Thus, the inhibition of activity by calcium is not due to proteolytic destruction or to irreversible denaturation of the enzyme system. By con- 


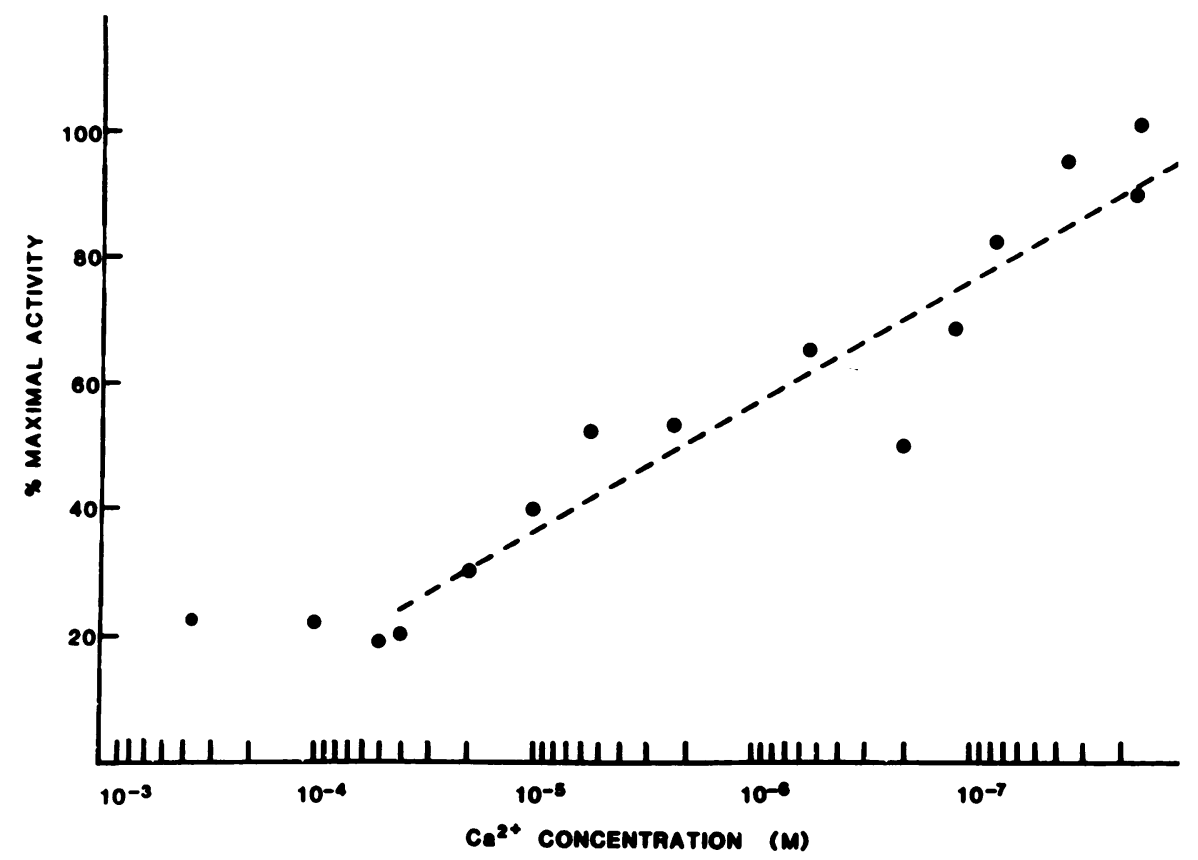

FIGURE $4 \mathrm{O}_{2}^{-}$production by phagocytic vesicles from rabbit alveolar macrophages as a function of free $\mathrm{Ca}^{2+}$ concentration. Phagocytic vesicles were washed in a medium containing $0.5 \mathrm{mg} / \mathrm{ml}$ albumin, $0.25 \mathrm{M}$ sucrose, $30 \mathrm{mM}$ imidazole- $\mathrm{HCl}, \mathrm{pH} 6.9,2.5 \mathrm{mM} \mathrm{MgCl}$, and $100 \mu \mathrm{M} \mathrm{CaCl}_{2}$, and assayed for $\mathrm{O}_{2}^{-}$production in the medium described in Fig. 1 (except that $100 \mathrm{mM} \mathrm{KCl}$ replaced the sucrose) at various concentrations of $\mathrm{Ca}$ and EGTA at $25^{\circ} \mathrm{C}$. The results are expressed as percent maximal activity that was obtained at the lowest $\mathrm{Ca}^{2+}$ tested. $\mathrm{A}$ maximal inhibition of $80 \%$ was detected at $40 \mu \mathrm{M}$ free $\mathrm{Ca}^{2+}$, and half maximal inhibition was documented at $0.7 \mu \mathrm{M}$ free $\mathrm{Ca}^{2+}$. The line was plotted by linear regression analysis $(r=0.94)$. Free $\mathrm{Ca}^{2+}$ concentrations were calculated as described in the test.

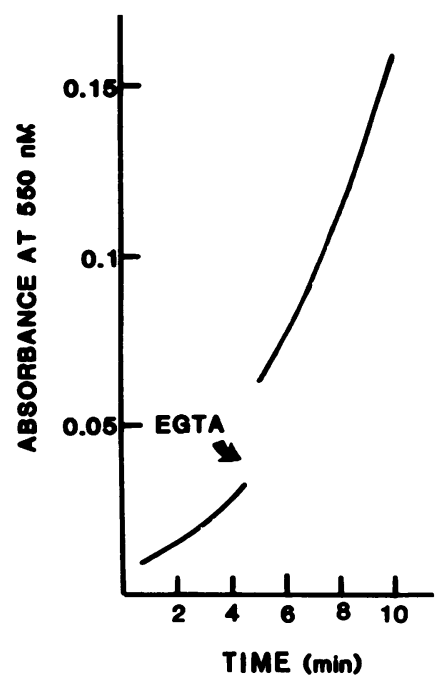

Figure 5 Time-course and reversibility of the effect of calcium on $\mathrm{O}_{2}^{-}$production by phagocytic vesicles. $\mathrm{O}_{2}^{-}$production by phagocytic vesicles was measured in a medium containing $100 \mathrm{mM} \mathrm{KCl}, 30 \mathrm{mM}$ imidazole- $\mathrm{HCl}, \mathrm{pH} 6.9,2.5$ $\mathrm{mM} \mathrm{MgCl}{ }_{2}, 40 \mu \mathrm{M}$ free $\mathrm{Ca}^{2+}, 0.5 \mathrm{mM} \mathrm{NADPH}, 50 \mu \mathrm{M}$ cytochrome $c$, and $30 \mu \mathrm{g}$ superoxide dismutase in the reference compartment at $25^{\circ} \mathrm{C}$. After $4 \mathrm{~min}, 400 \mu \mathrm{M}$ EGTA was added to both compartments of the spectrophotometer. trast, variations of $\mathrm{Mg}^{+2}$ concentration did not result in variations of enzyme activity.

Table II describes experiments that showed that calcium was required to maintain the calcium sensitivity of phagocytic vesicles. If vesicles were first incubated in buffers containing increasing concentrations of EGTA relative to calcium, there was a decrease in the subsequent calcium sensitivity, and the activity tested at either high or low calcium concentrations approached similar values. Reincubation of these desensitized phagocytic vesicles in the presence of higher calcium concentration for $10-20 \mathrm{~min}$ at $0^{\circ} \mathrm{C}$ restored calcium sensitivity to the enzyme activity (Table II, lines 1 and 3), although calcium sensitivity could not be restored to vesicles originally incubated in very high EGTA concentrations (Table II, line 5). These vesicles initially exposed to very high EGTA concentrations did not regain calcium sensitivity even if they were subsequently incubated with calcium for long periods of time (up to $600 \mu \mathrm{M}$ free $\mathrm{Ca}^{2+}$ for $3 \mathrm{~h}$ at $0^{\circ} \mathrm{C}$ ). If calcium was not added to the homogenate after cell rupture, permanent desensitization also occurred.

The effects of EGTA on desensitization could be 
TABLE II

Effect of EGTA, Trifluoperazine, and Calmodulin on the Specific

Activity and Calcium Sensitivity of NADPH-dependent

$\mathrm{O}_{2}^{-}$Production by Purified Phagocytic Vesicles

\begin{tabular}{|c|c|c|c|c|c|c|}
\hline \multicolumn{2}{|c|}{ First incubation } & \multicolumn{3}{|c|}{ Second incubation } & \multicolumn{2}{|c|}{$\begin{array}{c}\text { Conditions of assay for } \\
\mathrm{O}_{\mathbf{2}}^{-} \text {generation }\end{array}$} \\
\hline$\overline{\mathrm{CaCl}_{2}}$ & $\overline{\text { EGTA }}$ & $\begin{array}{c}\mathrm{Ca}^{+2} \\
(100 \mu \mathrm{M})\end{array}$ & $\begin{array}{c}\text { Trifluoperazine } \\
(250 \mu \mathrm{M})\end{array}$ & $\begin{array}{l}\text { Calmodulin } \\
(20 \mu \mathrm{M})\end{array}$ & $\begin{array}{c}\mathrm{Ca}^{+2 *} \\
(100 \mu \mathrm{M})\end{array}$ & $\begin{array}{c}\mathrm{Ca}^{+2 *} \\
(0.016 \mu \mathrm{M})\end{array}$ \\
\hline$\mu M$ & $\mu M$ & & & & & \\
\hline 20 & 0 & + & - & - & $4.7 \pm 1.5$ & $26.0 \pm 3.0$ \\
\hline 20 & 0 & + & + & - & $4.2 \pm 1.3$ & $24.0 \pm 2.0$ \\
\hline 20 & 100 & + & - & - & $7.0 \pm 0.8$ & $29.0 \pm 2$ \\
\hline 20 & 100 & + & - & + & $8.0 \pm 1.0$ & $31.0 \pm 2.0$ \\
\hline 20 & 1,000 & + & - & - & $14.2 \pm 1.5$ & $20.3 \pm 1.8$ \\
\hline 20 & 1,000 & + & - & + & $13.37 \pm 2.0$ & $19.1 \pm 2.2$ \\
\hline
\end{tabular}

Purified phagocytic vesicles were suspended in the presence of calcium/EGTA mixtures to give high or low free calcium concentrations as indicated in the left column for $5 \mathrm{~min}$ at $0^{\circ} \mathrm{C}$ (first incubation). Calcium was then added in express (final free $\left.\left\{\mathrm{Ca}^{+2}\right\} 100 \mu \mathrm{M}\right)$ in the presence or absence of calmodulin or trifluoperazine as indicated in the middle column (second incubation). After $1 \mathrm{~h}$ at $0^{\circ} \mathrm{C}$, samples were tested for $\mathrm{O}_{2}^{-}$production in the medium described in Fig. 5 at the final calcium concentrations indicated in the right column. The samples incubated in the presence of trifluoperazine were also tested in the presence of trifluoperazine $(250 \mu \mathrm{M})$.

* Free calcium concentration calculated as described in the text.

compatible with the dissociation of a calcium-binding protein from the phagocytic vesicles at low calcium concentrations. Therefore, as shown also in Table II, several experiments were performed to see whether the observed effect was mediated by the ubiquitous calcium-binding protein, calmodulin. First, vesicles prepared in the presence of calcium were incubated in the presence of trifluoperazine and calcium (Table II, line 2). In contrast to the $\mathrm{O}_{2}^{-}$release by intact cells, incubation of vesicles in the presence of $250 \mu \mathrm{M}$ trifluoperazine did not decrease the specific activity or the calcium sensitivity of the $\mathrm{O}_{2}^{-}$-generating activity of sensitive vesicles. Addition of rabbit alveolar macrophage or bovine brain calmodulin did not restore the calcium sensitivity to desensitized vesicles and did not alter their $\mathrm{O}_{2}^{-}$production rates (Table II, line 6).

As found with phagocytic vesicles, the $\mathrm{O}_{2}^{-}$-generating activity of podosomes obtained from digitoninstimulated macrophages was inhibited by micromolar concentrations of calcium. In a medium containing $0.25 \mathrm{M}$ sucrose, $2.5 \mathrm{mM} \mathrm{MgCl}$, and $30 \mathrm{mM}$ imidazole$\mathrm{HCl}, \mathrm{pH} 6.9$, the activity in the presence of $0.1 \mathrm{mM}$ free $\mathrm{Ca}^{2+}$ was $52 \%$ of that measured in the presence of $0.016 \mu \mathrm{M} \mathrm{Ca}^{2+}$. We were unable to activate podosomes of unstimulated macrophages by extensive washing in EGTA or by addition of Mg-ATP and extracts of macrophages in the presence of calcium.

\section{DISCUSSION}

Alveolar macrophages exposed to a variety of stimuli, including opsonized zymosan, phorbol myristate acetate, $\boldsymbol{N}$-formylmethionyl peptides, concanavalin $\mathrm{A}$, and digitonin, generate superoxide after a lag period (3, 18-20). We have confirmed these previous observations and extended them to show that the $\mathrm{O}_{2}^{-}$-generating system of intact macrophages is insensitive to trypsin and inhibited by trifluoperazine.

Phagocytic vesicles purified from macrophages that have ingested opsonized lipopolysaccharide-coated diisodecylphtalate particles possess an $\mathrm{NAD}(\mathrm{P}) \mathrm{H}-$ dependent, $\mathrm{O}_{2}^{-}$-generating system. It shares several common features with the extensively characterized activity described in several preparations of polymorphonuclear leukocytes, including similar ranges of reduced pyridine nucleotide requirements, $\mathrm{pH}$ optimum, and insensitivity to $\mathrm{CN}^{-}(10,21-23)$.

It is possible that phagocytic vesicles might not be representative of the composition of plasma membrane as a whole either because of fusion of the vesicle membranes with lysosomal membranes or because of lateral segregation of membrane molecules out of the vacuoles during phagocytosis. However, we found an NADPH-dependent, $\mathrm{O}_{2}^{-}$-generating system with the features of the phagocyte vesicle system, although of lower specific activity, in peripheral plasma 
membrane vesicles prepared by gentle sonication of macrophages (podosomes). These vesicles are peripheral blebs of macrophage plasma membrane, which are representative of the total cell plasma membrane with respect to the marker adenylate cyclase and externally labeled proteins (9). Electron micrographs of these vesicles contain some empty sacs that have filaments on their outer surfaces (9). Although the bulk of these blebs appears to be rightside-out vesicles, the $\mathrm{O}_{2}^{-}$generation presumably takes place in the small subpopulation of inverted vesicles, because in contrast to intact macrophages, the $\mathrm{O}_{2}^{-}$-generating activity by podosomes as well as phagocytic vesicles was trypsin sensitive and dependent upon the addition of $\mathrm{NAD}(\mathrm{P}) \mathrm{H}$, which does not permeate intact membranes. The present findings are further evidence that the activated oxidase enzyme is present in the plasmalemma (24-26) and internalized into the phagocytic vacuole during phagocytosis.

When neutrophils are incubated in the presence of opsonized particles and the particulate fraction or phagocytic vesicles isolated at various times after initiation of phagocytosis, a rapid decrease in specific activity occurs after incubations $>10 \min (23,27)$. By contrast, the phagocytic vesicles isolated from macrophages maintained the same specific activity even 90 min after initiation of phagocytosis. Thus, once internalized from the plasma membrane into the phagocytic vesicle, the active enzyme can apparently function for prolonged periods of time. This ability to sustain oxidative activity is important for macrophages that reside for long times in inflammatory sites (28).

The most novel finding of this study was the discovery of an inhibitory effect of calcium on the $\mathrm{O}_{2}^{-}$generating activity of macrophage phagocytic vesicles and podosomes. Although the free $\mathrm{Ca}^{2+}$ concentration in the cytoplasm of macrophages has not yet been measured, in other cells, particularly muscle and nerve, the free $\mathrm{Ca}^{2+}$ concentrations can fluctuate between $10 \mathrm{nM}$ and $10 \mu \mathrm{M}$, according to the state of stimulation $(29,30)$. This range of calcium concentrations influenced $\mathrm{O}_{2}^{-}$-generating activity by macrophage phagocytic vesicles in NADPH under physiological ionic conditions ( $100 \mathrm{mM} \mathrm{KCl}, 2.5 \mathrm{mM} \mathrm{MgCl}_{2}, \mathrm{pH} 6.9$ ). The effect was rapid and reversible, conditions necessary for an effective control of enzyme activity.

The inhibitory effect of calcium that we have observed is exerted upon the activated enzyme that is present in phagocytic vesicles. The role of calcium, if any, in the activation process of the $\mathrm{O}_{2}^{-}$-generating system remains to be determined. Podosomes obtained from digitonin-stimulated macrophages had much higher rates of $\mathrm{O}_{2}^{-}$production than podosomes obtained from unstimulated macrophages. However, we were unable to activate podosomes of unstimulated macrophages by extensive washing in EGTA or by addition of Mg-ATP and extracts of macrophages in the presence of calcium.

It is not clear from the present experiments if the effect of calcium is directly on the membrane-bound enzyme or mediated by a calcium-binding component that is washed away in the presence of EGTA. Calmodulin, a ubiquitous calcium-binding protein that acts as a calcium regulatory subunit of many intracellular enzymes (31), is appealing to be this component. However, the results of several experiments argue against a direct involvement of calmodulin in our system. First, purified calmodulin did not restore calcium sensitivity to vesicles that had lost it after exposure to EGTA. Second, trifluoperazine, a drug that binds to calmodulin with high affinity in the presence of calcium, did not change the specific activity nor the calcium sensitivity of $\mathrm{O}_{2}^{-}$formation by phagocytic vesicles in the presence of $0.5 \mathrm{mM}$ NADPH. By contrast, trifluoperazine at lower concentrations increased the activation period and inhibited the $\mathrm{O}_{2}^{-}$-generating system of intact stimulated macrophages whether added before or after establishment of the maximal rates of $\mathrm{O}_{2}^{-}$production.

We recently reported that the plasma membrane of macrophages contains a Mg-ATP-dependent calcium pump that transports calcium from the cytoplasmic to the external membrane surface against an electrochemical gradient. The activity of the pump is stimulated by calmodulin and inhibited by trifluoperazine (32). A slight decrease in the activity of this calcium pump activity could possibly cause an increase of the cytoplasmic free $\mathrm{Ca}^{2+}$ concentration. Therefore, some of the inhibitory effect of trifluoperazine on the $\mathrm{O}_{2}^{-}$generating system of intact cells could be due to increased calcium at the inner side of the plasma membrane. However, the trifluoperazine effect on whole cells could be due to other calmodulin-mediated reactions, to competition with NADPH for the oxidase, or to nonspecific or toxic effects $(31,33)$. In any case, we speculate that, in order to obtain maximal $\mathrm{O}_{2}^{-}$generating rates, the calcium concentration has to decrease in the membrane region containing the activated enzyme.

\section{ACKNOWLEDGMENTS}

We are indebted to Mrs. Esther Campos and Ms. Kitty G. Brown for their valuable secretarial assistance.

This work was supported by U. S. Public Health Service training grant CA 09321 and grants from the Swiss Foundation for Scientific Research, Swiss Foundation for Scholarships in Medicine and Biology, and the Swiss Society of Internal Medicine.

\section{REFERENCES}

1. Babior, B. M. 1978. Oxygen-dependent microbial killing by phagocytes. $N$. Engl. J. Med. 298: 659-668; 721-725.

2. Cohen, H. J., and M. E. Chovaniec. 1978. Superoxide 
generation by digitonin-stimulated guinea pig granulocytes. A basis for a continuous assay for monitoring superoxide production and for the study of the activation of the generating system. J. Clin. Invest. 61: 10811087.

3. Cohen, H. J., and M. E. Chovaniec. 1978. Superoxide production by digitonin-stimulated guinea pig granulocytes. The effects of $\mathrm{N}$-ethylmaleimide, divalent cations, and glycolytic and mitochondrial inhibitors on the activation of the superoxide generating system. J. Clin. Invest. 61: $1088-1096$.

4. Yin, H. L., and T. P. Stossel. 1979. Control of cytoplasmic actin gel-sol transformation by gelsolin, a calcium-dependent regulatory protein. Nature (Lond.). 281: 583-586.

5. Myrvik, Q. N., E. S. Leake, and B. Fariss. 1961. Studies on pulmonary alveolar macrophages from the normal rabbit: a technique to procure them in a high state of purity. J. Immunol. 86: 128-136.

6. Stossel, T. P., R. J. Mason, T. D. Pollard, and M. Vaughan. 1972. Isolation and properties of phagocytic vesicles. II. Alveolar macrophages. J. Clin. Invest. 51: 604-614.

7. Stossel, T. P., R. J. Field, J. D. Gitlin, C. A. Alper, and F. S. Rosen. 1975. The opsonic fragment of the third component of human complement (C3). J. Exp. Med. 141: $1329-1347$.

8. Lowry, O. H., N. J. Rosebrough, A. L. Farr, and R. J. Randall. 1951. Protein measurement with the Folin phenol reagent. J. Biol. Chem. 193: 265-275.

9. Davies, W. A., and T. P. Stossel. 1977. Peripheral hyaline blebs (podosomes) of macrophages. J. Cell Biol. 75: 941-955.

10. Cohen, H. J., M. E. Chovaniec, and W. A. Davies. 1980. Activation of the guinea pig granulocyte NAD(P)Hdependent superoxide generating enzyme: localization in a plasma membrane enriched particle and kinetics of activation. Blood. 55: 355-363.

11. Chance, B., and G. R. Williams. 1956. The respiratory chain and oxidative phosphorylation. In Advances in Enzymology. F. F. Nord, editor. Interscience Publishers, Inc., New York.

12. Sillen, L. G., and A. E. Martell. 1964. Stability Constants of Metal Ion Complexes. The Chemical Society. Burlington House, London. 2nd edition.

13. Potter, J. D., and J. Gergely. 1975. The calcium and magnesium binding sites on troponin and their role in the regulation of myofibrillar adenosine triphosphatase. $J$. Biol. Chem. 250: 4628-4633.

14. Charbonneau, H., and M. J. Cormier. 1979. Purification of plant calmodulin by fluphenazine-sepharose affinity chromatography. Biochem. Biophys. Res. Commun. 90: 1039-1047.

15. Strewler, G. J., V. C. Manganiello, and M. Vaughan. 1978. Phosphodiesterase activator from rat kidney cortex. J. Biol. Chem. 253: 390-394.

16. Levin, R. M., and B. Weiss. 1977. Binding of trifluoroperazine to the calcium-dependent activator of cyclic nucleotide phosphodiesterase. Mol. Pharmacol. 13: $695-697$.
17. Rister, M., and R. O. Baehner. 1976. A comparative study of superoxide dismutase activity in polymorphonuclear leukocytes, monocytes, and alveolar macrophages of the guinea pig. J. Cell. Physiol. 87: 345-356.

18. Drath, D. B., and M. L. Karnovsky. 1975. Superoxide production by phagocytic leukocytes. J. Exp. Med. 141: 257-262.

19. Boxer, L. A., G. Ismail, J. M. Allen, and R. L. Baehner. 1979. Oxidative metabolic responses of rabbit pulmonary alveolar macrophages. Blood. 53: 486-491.

20. Holian, A., and R. P. Daniele. 1979. Stimulation of oxygen consumption and superoxide anion production in pulmonary macrophages by $\mathrm{N}$-formyl methionyl peptides. FEBS (Fed. Eur. Biochem. Soc.) Lett. 108: 47-50.

21. Babior, B. M., J. T. Curnutte, and B. J. McCurrich. 1976. The particulate superoxide-forming enzyme from human neutrophils. J. Clin. Invest. 58: 989-996.

22. Badwey, J. A., and M. L. Karnovsky. 1979. Production of superoxide and hydrogen peroxide by an NADH oxidase in guinea pig polymorphonuclear leukocytes. Modulation by nucleotides and divalent cations. $J$. Biol. Chem. 254: 11530-11537.

23. Cohen, H. J., P. E. Newburger, and M. E. Chovaniec. 1980. NAD $(\mathrm{P}) \mathrm{H}$-dependent superoxide production by phagocytic vesicles from guinea pig and human granulocytes. J. Biol. Chem. 255: 6584-6588.

24. Briggs, R. T., D. B. Drath, M. L. Karnovsky and M. J. Karnovsky. 1975. Localization of NADH oxidase on the surface of human polymorphonuclear leukocytes by a new cytochemical method. J. Cell Biol. 67: 566-586.

25. Goldstein, I. M., M. Cerqueira, S. Lind, and M. B. Kaplan. 1977. Evidence that the superoxide-generating system of human leukocytes is associated with the cell surface. J. Clin. Invest. 59: 249-254.

26. Dewald, B., M. Baggiolini, J. T. Curnutte, and B. M. Babior. 1979. Subcellular localization of the superoxide-forming enzyme in human neutrophils. J. Clin. Invest. 63: 21-29.

27. Jandl, R. C., J. A. Schwartz, L. Borges-DuBois, R. S. Kipnes, B. J. McMurrich, and B. M. Babior. 1978. Termination of the respiratory burst in human neutrophils. J. Clin. Invest. 61: 1176-1185.

28. Nathan, C., N. Noguiera, C. Jaunqbhanich, J. Ellus, and $\mathrm{Z}$. Cohn. 1979. Activation of macrophages in vivo and in vitro. Correlation between hydrogen peroxide release and killing of trypanosoma cruzzi. J. Exp. Med. 149: $1056-1068$.

29. Ashley, C. C. 1978. Calcium ion regulation in barnacle muscle fiber and its relation to muscle development. Ann. N. Y. Acad. Sci. 307: 308-329.

30. Rasmussen, H., and M. C. Gustin. 1978. Some aspects of the hormonal control of cellular calcium metabolism. Ann N. Y. Acad. Sci. 307: 391-401.

31. Cheung, W. Y. 1980. Calmodulin plays a pivotal role in cellular regulation. Science (Wash. D.C.) 207: 19-27.

32. Lew, D. P. and T. P. Stossel. 1980. Calcium transport by macrophage plasma membranes. J. Biol. Chem. 255: 5841-5846.

33. Cohen, H. J., M. E. Chovaniec, and S. E. Ellis. 1980. Chlorpromazine inhibition of granulocyte superoxide production. Blood. 56: 23-29. 